\title{
Calcification of umbilical artery: two distinct lesions
}

\author{
T Y KHONG, ${ }^{*}$ S A DILLY
}

\begin{abstract}
From the *Department of Paediatric Pathology, John Radcliffe Hospital, Oxford, and the Department of Histopathology, St George's Hospital Medical School, London
\end{abstract}

SUMMARY The clinical and pathological features of five cases of calcification of umbilical cord vessels were reviewed. Two distinct lesions were identified: calcification could produce either sclerosis of the wall or obliteration of the lumen. In three cases there was calcification within the media and adventitia of the umbilical arteries, with extension into Wharton's jelly in one case. The pathogenesis of this pattern of calcification - the sclerotic variant-is unclear but the findings of inflammation in the umbilical cord and its vessels, membranes, and decidua suggest intrauterine infection. In two cases there was complete calcification of umbilical arterial lumina resulting in total obliteration. The findings of fetal vessels in the chorionic plate with medial calcification in one of these two cases raises the possibility of thrombosis within the umbilical cord vessels as a cause, but the latter was not found. One infant from each group was liveborn. Both had shown signs of fetal distress in utero and delivered prematurely. The other three pregnancies resulted in macerated stillbirth preterm.

Calcification of umbilical cord vessels is rare. ${ }^{1}$ Previous reports have described clinical and pathological features associated with calcification of the vessel wall, ${ }^{1-4}$ but the paucity of reports suggest that it is an exceedingly rare occurrence. We report three further cases of umbilical vessel wall calcification and two cases of complete calcification of the umbilical arterial lumen, the latter phenomenon not previously reported.

Accepted for publication 20 April 1989

\section{Case reports and pathological findings}

The clinical data are shown in table 1 and a summary of the pathological findings in table 2 . The striking feature in cases 1 and 2 was the complete calcification of umbilical arterial lumina resulting in total obliteration (fig 1). This is different from that seen in cases 3,4 , and 5 where the calcification was within the media and adventitia of the umbilical arteries (fig 2). Calcification of the vessel wall affected only one vessel in cases 3 and 5 but affected all three vessels in the umbilical cord

Table 1 Clinical data

\begin{tabular}{|c|c|c|c|c|c|c|c|}
\hline $\begin{array}{l}\text { Case } \\
\text { No }\end{array}$ & Age & Gravidity & Ethnic origin & Maternal history & $\begin{array}{l}\text { Gestational } \\
\text { age }\end{array}$ & Delivery & Outcome \\
\hline 1 & 24 & G2P1 & Occidental & $\begin{array}{l}\text { Angioneurotic oedema, } \\
\text { urticaria, } \\
\text { polyarthropathy } \\
\text { Diagnosed as "lupus- } \\
\text { like" treated with } \\
\text { prednisolone and } \\
\text { azathioprine }\end{array}$ & 35 & $\begin{array}{l}\text { Caesarean } \\
\text { section for } \\
\text { fetal distress }\end{array}$ & $\begin{array}{l}\text { Liveborn male, } \\
1480 \mathrm{~g}\end{array}$ \\
\hline 2 & 19 & G1 & Occidental & $\begin{array}{l}\text { Skin irritation and rash } \\
\text { at } 28 \text { weeks gestation }\end{array}$ & 34 & $\begin{array}{l}\text { Induced labour } \\
\text { for intra- } \\
\text { uterine death }\end{array}$ & $\begin{array}{l}\text { Macerated } \\
\text { female, } 940 \mathrm{~g}\end{array}$ \\
\hline 3 & 43 & G1 & Oriental & Premature labour & 32 & $\begin{array}{l}\text { Caesarean } \\
\text { section for } \\
\text { fetal distress }\end{array}$ & $\begin{array}{l}\text { Liveborn male, } \\
1350 \mathrm{~g}\end{array}$ \\
\hline 4 & 22 & $\mathbf{G} 2 \mathbf{P O}+1$ & Occidental & - & 25 & $\begin{array}{l}\text { Induced labour } \\
\text { for intra- } \\
\text { uterine death }\end{array}$ & $\begin{array}{l}\text { Macerated male, } \\
619 \mathrm{~g}\end{array}$ \\
\hline 5 & 21 & $\mathrm{G} 2 \mathrm{PO}+1$ & Occidental & - & 32 & $\begin{array}{l}\text { Induced labour } \\
\text { for intra- } \\
\text { uterine death }\end{array}$ & $\begin{array}{l}\text { Macerated } \\
\text { female, } 1650 \mathrm{~g}\end{array}$ \\
\hline
\end{tabular}


Table 2 Pathological findings

\begin{tabular}{|c|c|c|c|}
\hline Case No & Necropsy & Placenta & Histology \\
\hline 1 & Not relevant & $292 \mathrm{~g}, 20 \%$ infarction & $\begin{array}{l}\text { Complete calcification of umbilical } \\
\text { arterial lumen }\end{array}$ \\
\hline 2 & $\begin{array}{l}\text { Permission refused; externally loss of } \\
\text { fingers and toes due to amniotic } \\
\text { rupture syndrome }\end{array}$ & $\begin{array}{l}460 \mathrm{~g} \text {, cord twisted round partially } \\
\text { detached amniotic epithelium }\end{array}$ & $\begin{array}{l}\text { Thrombosis of fetal vessels in chorionic } \\
\text { plate with medial calcification } \\
\text { Complete calcification of umbilical } \\
\text { arterial lumen }\end{array}$ \\
\hline 3 & $\begin{array}{l}\text { Not relevant (umbilical artery } \\
\text { catheter passed easily into preterm } \\
\text { neonate) }\end{array}$ & $393 \mathrm{~g}$ & $\begin{array}{l}\text { Endarteritis with medial and adventitial } \\
\text { proliferation and coarse calcification } \\
\text { of one umbilical artery; fine } \\
\text { calcification around the other two } \\
\text { vessels } \\
\text { Mild chorioamnionitis and acute } \\
\text { decidualitis present }\end{array}$ \\
\hline 4 & Maceration changes & $\begin{array}{l}186 \mathrm{~g} \text {, oedematous cord with } \\
\text { narrowing at fetal insertion }\end{array}$ & $\begin{array}{l}\text { Endarteritis with fine calcification of } \\
\text { adventitia of both umbilical arteries } \\
\text { and umbilical vein } \\
\text { Funisitis and chorioamnionitis also } \\
\text { present }\end{array}$ \\
\hline 5 & Maceration changes & $\begin{array}{l}360 \mathrm{~g} \text {, umbilical cord showed marked } \\
\text { circumferential fibrosis and } \\
\text { calcification around all } 3 \text { vessels }\end{array}$ & $\begin{array}{l}\text { Vasculitis and thrombosis of fetal } \\
\text { vessels in chorionic plate with } \\
\text { calcification of some of the contents } \\
\text { Funisitis and vasculitis with } \\
\text { calcification of part of the adventitia } \\
\text { of one umbilical artery with extension } \\
\text { into Wharton's jelly }\end{array}$ \\
\hline
\end{tabular}

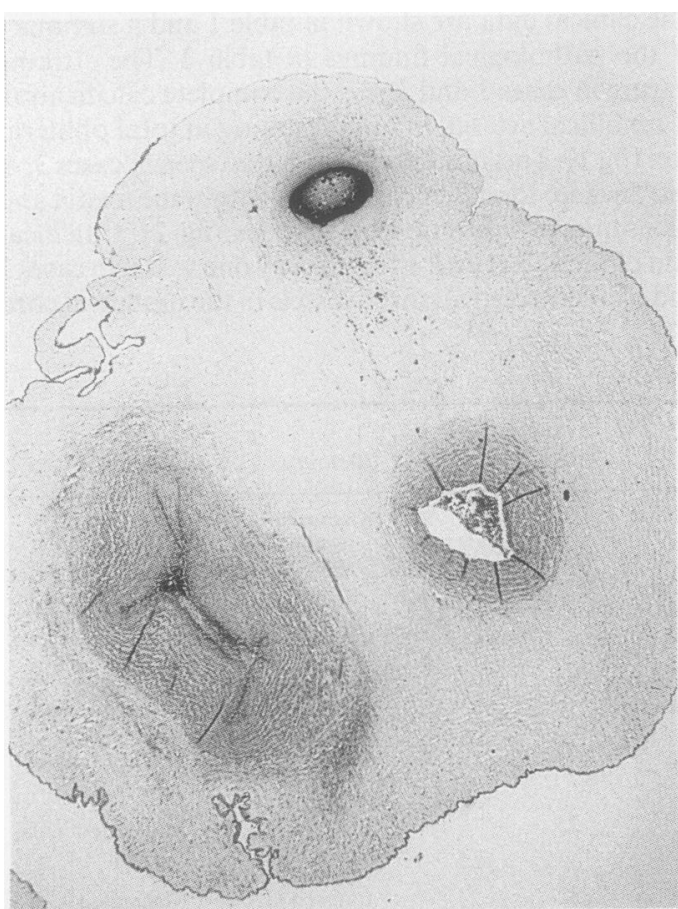

Fig 1 Case 1: complete occlusion of arterial lumen by calcification. (Haematoxylin and eosin.)

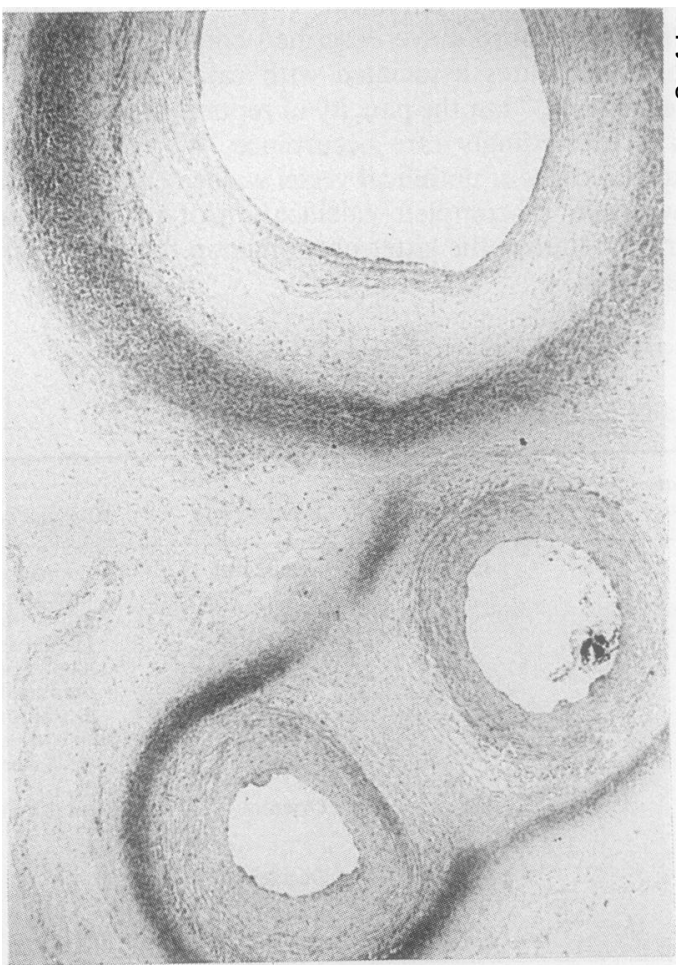

Fig 2 Case 3: calcification of media and adventitia of umbilical arteries and vein. (Haematoxylin and eosin.) 


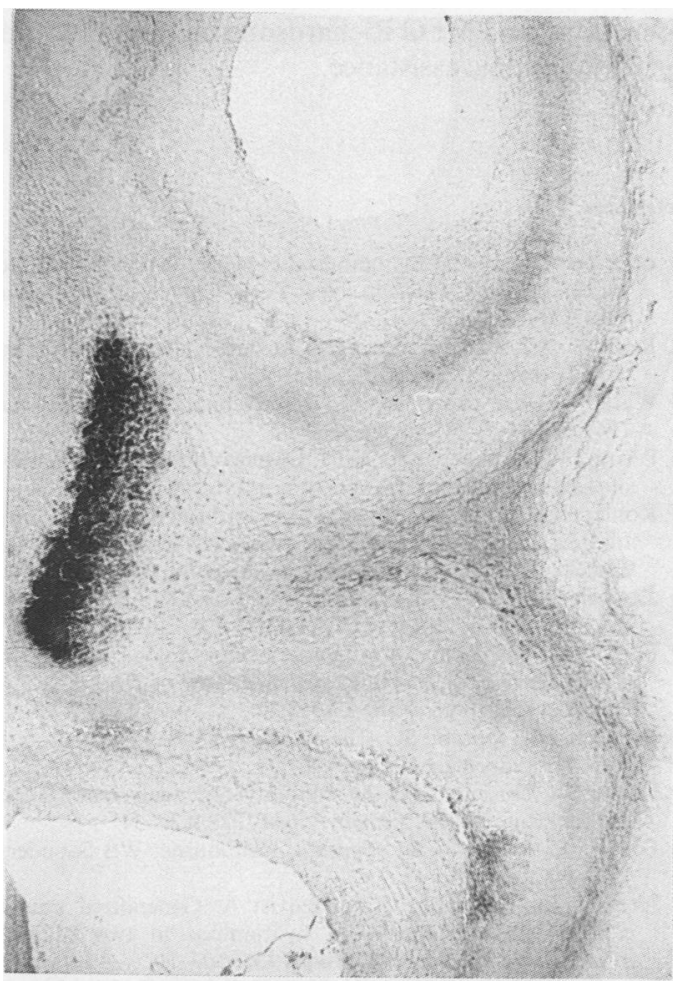

Fig 3 Case 5: fine calcification of umbilical artery with dense calcification in Wharton's jelly. (Haematoxylin and eosin.)

of case 4. Calcification was seen in Wharton's jelly in case 5 (fig 3). Thrombosis of fetal vessels in the chorionic plate with either calcification of the media or the contents was seen in cases 2 and 5 (fig 4). Gram stains did not show the presence of organisms.

\section{Discussion}

Because placentas are examined on a semi-selective basis the exact prevalence of calcification of umbilical cord vessels is not known. We believe, however, that the condition is rare as these five cases were found from archival material over a 13 year period (19751988 ) in Oxford and over a five year period (19831988) at St George's Hospital, London.

Calcification of umbilical cord vessels can take one of two forms producing obliteration on the one hand and sclerosis on the other. deSa distinguished between calcification of umbilical cord vessels and sclerosing funisitis or constrictive sclerosis of Wharton's jelly. 'In the former, there is calcification of the cord vessel wall while in the latter there is often calcification of an attenuated and sclerosed Wharton's jelly. Our third and fourth cases showed calcification predominantly

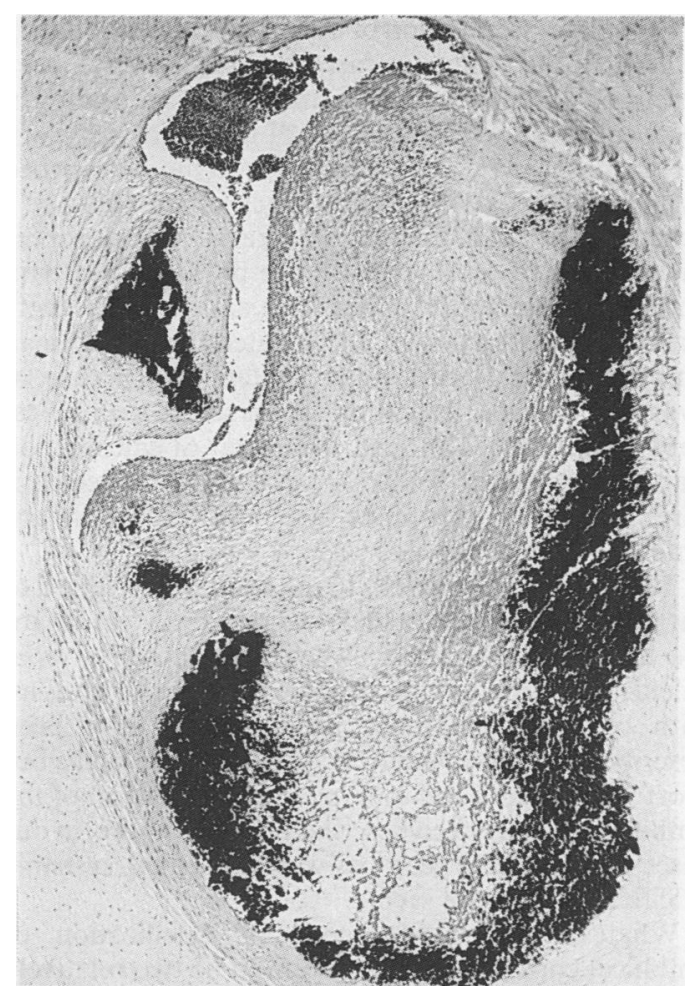

Fig 4 Case 2: calcification of thrombus and media of chorionic plate artery. (Haematoxylin and eosin.)

in the adventitia while our fifth case showed calcification within Wharton's jelly as well as within the wall of the blood vessels; it is our contention that it is difficult to ascertain the primary site of calcification. This is not surprising as the adventitia merges imperceptibly with the surrounding Wharton's jelly and Wharton's jelly has been likened to the adventitia of the umbilical arteries. ${ }^{6}$ It would seem more appropriate to classify these as sclerosing calcification in contrast to the obliterative lesion seen in cases 1 and 2. Blanc suggested that calcified umbilical cord vessels were due to intrauterine viral infections ${ }^{7}$ while deSa thought that sclerosing funisitis was a response to any infection. ${ }^{1}$ In none of our cases, however, was there evidence of villitis or viral inclusions, but the findings of decidualitis (case 3), funisitis (cases 4 and 5), chorioamnionitis (cases 3 and 4) and endarteritis or vasculitis (cases 3, 4, and 5) suggest intrauterine infection. Bacteriological studies on the mothers were negative. Sclerosing calcification of umbilical vessels has been found in association with fetal hydrops following fetomaterial haemorrhage,' Salla disease, ${ }^{1}$ fetal renal calcification, ${ }^{4}$ normal liveborn infants ${ }^{1-3}$ and macerated stillbirths. ${ }^{14}$ 
Complete calcification of the umbilical artery lumen as seen in our first two cases has not hitherto been described. Its pathogenesis is unclear but the finding of focal calcification of thrombus of the major vessels in the chorionic plate in case 2 , similar to those described by Benirschke and Driscoll, ${ }^{8}$ suggests that it may be a degenerative phenomenon, as a result of dystrophic calcification of a thrombus more proximally. Perrin and Kahn-Vander Bel presented a case in which there was focal calcification of a laminated thrombus in an umbilical cord vessel ${ }^{4}$ while Heifetz had a case of "vascular mural calcification" in his series of umbilical cord thrombosis, although the extent of calcification was not illustrated. ${ }^{9}$ Thrombosis of umbilical vessels is rare, ${ }^{510}$ and a thrombus was not found in the umbilical cords of cases 1 or 2 .

These cases are different to the condition referred to variably as idiopathic arterial calcification ${ }^{11}$ or infantile arterial calcification ${ }^{12}$ where generalised arterial calcification, including coronary and renal arteries, with or without intimal proliferation, have been described. In that condition, some were stillbirths but most were infants and in none has calcification of the umbilical arteries been described. Furthermore, in our cases 4 and 5 where necropsy was performed, systemic calcification was not seen.

Whatever the pathogenesis of calcification of umbilical cord vessels, there seem to be two relatively distinctive patterns, either calcification leading to complete obliteration of the arterial lumen or calcification of the arterial wall with or without involvement of Wharton's jelly. A possible cause for the first is thrombosis and, for the second, infection.

We thank the clinicians Mr D H Barlow, J M Pearce, J H Hughes, S C Simmons for their permission to report these cases, Dr J W Keeling for helpful discussions, and Mr G Richardson and Miss H Mellor for photographic assistance.

\section{References}

1 deSa DJ. Diseases of the umbilical cord. In: Perrin EVDK, ed. Pathology of the Placenta. New York: Churchill Livingstone, 1984:128-33.

2 Rust W. Seltsame veraderungen an den Nabelschnurgefassen. Arch Gynak 1937;165:58-62.

3 Walz W. Uber das odem der Nabelschnur. Zentralbl Gynak 1947;69:144-5.

4 Perrin EVD, Kahn-Vander Bel J. Degeneration and calcification of the umbilical cord. Obstet Gynecol 1965;26:371-6.

5 Kohler HG. Pathology of the umbilical cord and fetal membranes. In: Fox H, ed. Haines and Taylor obstetrical and gynaecological pathology. Edinburgh: Churchill Livingstone, 1987:1079-116.

6 Zawisch C. Die Wharton'sche sulze und die Gefasse des Nabelstranges. Zeitsch Zellforsch 1955;42:94-133, cited by Kohler.'

7 Blanc WA. The future of antepartum morphologic studies. In: Adamsons K, ed. Diagnosis and treatment of fetal disorders. New York: Springer-Verlag, 1968:20.

8 Benirschke K, Driscoll SG. The pathology of the human placenta. New York: Springer-Verlag, 1967:83.

9 Heifetz SA. Thrombosis of the umbilical cord: analysis of 52 cases and literature review. Pediatr Pathol 1988;8:37-54.

10 Fox H. Pathology of the Placenta. Eastbourne: WB Saunders, $1978: 445$.

11 Ivemark BI, Lagergren C, Ljungqvist A. Generalized arterial calcification associated with hydramnios in two stillborf infants. Acta Paediatr 1962;(Suppl 135):103-10.

12 Van Dyck M, Proesmans W, Van Hollebeke E, Marchal G. Moerman $\mathrm{Ph}$. Idiopathic infantile arterial calcification with cardiac, renal and central nervous system involvement. Eur $\bar{F}$ Pediatr 1989;148:374-7.

Requests for reprints to: Dr T Y Khong, Department of Paediatric Pathology, John Radcliffe Hospital, Oxford OX3 9DU, England. 